\title{
O direito à informação e o dever de informar
}

\section{Resumo}

O direito à informação e o dever de informar assumem condições novas no contexto de uma sociedade cada vez mais mediada pelo ciberespaço. O presente texto discute estas questões no contexto do jornalismo contemporâneo apontando caminhos por onde a temática hoje pode ser situada.

\section{A composição do cenário}

Direito à informação e o dever de informar é um tema que possibilita uma diversidade de enfoques, especialmente se relacionado ao campo do jornalismo e às suas conceituações mais contemporâneas, nas quais a internet surge com força em seu processo de expressão e difusão. Com isso, consideramos oportuno iniciar este ensaio pelas conceituações básicas que o sustentarão.

Partimos, portanto, de um posicionamento do jornalismo contemporâneo da era digital. Na visão do professor Manuel Carlos Chaparro o texto jornalístico "é o relato verdadeiro e compreensível da atualidade, cuja finalidade primordial seria 'asseverar', do latim asseverare, que significa afirmar com certeza, com segurança"1. Chaparro avança ainda mais quando relaciona seu conceito ao direito à informação e à opinião às âncoras éticas do jornalismo, embora ao mesmo tempo questione sobre qual informação e qual opinião.

Para Chaparro, o jornalismo é avaliado e avalizado pelas razões do interesse público e de certos atributos de relevância, como atualidade, proximidade, notoriedade, conflito, conhecimento, curiosidade, dramaticidade e surpresa. A finalidade da ação social de informar esgota-se ao atingir este objetivo, e o que acontece após a recepção da informação faz parte da esfera do receptor, inserido em circunstâncias sociais e interesses específicos. As ações e comportamentos decorrentes da atuação do receptor realimentariam o processo social, provocando mudanças no cenário da atualidade e na ordenação ética e moral da sociedade.

Assim, a relação entre o direito e o dever de informar, na visão contemporânea de Manuel Chaparro, tem um vínculo intrínseco com as ações e reações dos receptores. Um cenário bastante similar à bidirecionalidade de relacionamentos do mundo digital.

A práxis deste jornalismo na era digital inclui sua vinculação aos cenários de inovação tecnológica e economia da globalização. Segundo Corrêa ${ }^{2}$ : 'Tanto para os mais ardorosos defensores e fãs, quanto para os mais ferrenhos críticos, considerar a informação como construtora da opinião de grupos sociais e como elemento de inclusão e coesão da sociedade - funções primordiais do jornalismo - parece estar irreversivelmente vinculado à tecnologia [...] O jornalismo no ciberespaço ou no mundo digital (qual seja o termo) potencializa-se no alcance, na amplitude e também na profundidade, criando um novo conjunto de possibilidades ao exercício e fortalecimento de suas funções fundamentais [...] um negócio ainda em formação pelas empresas informativas, seus publishers e especialmente, pelos profissionais que alimentam todo esse processo formador".

Como conseqüência dos posi-

\section{(1) CHAPARRO, Manuel Carlos. A pragmática do jornalismo. São Paulo: Summus, 1993. (2)CORRÊA, Elizabeth Saad. As estratégias da desconstrução: sobre o uso de estratégias diferenciadas por empresas informativas na internet. São Paulo: ECA-USP, Tese de Livre- Docência, nov. 2001.}

Elizabeth Saad Corrêa é professora e pesquisadora do Departamento de Jornalismo e Editoração - Núcleo de Jornalismo, Mercado e Tecnologia da ECA-USP. Coordenadora Acadêmica e Presidente do Conselho Gestor do USPOnline e autora, entre outros, do livro Empresas de tecnologia avançada: um manual para novos empresários, Promocet, 1986. 
(3) ACCARDO, Alain. Derrière la subjectivité des journalistes. Le Monde Diplomatique, Maio 200,

p.2. Acessado em http:// www.monde-diplomatique.fr/2000/ 05/ACCARDO/13807. (4) LEPRI, Sergio. Novos programas, novas máquinas: a internet vai permanecer como um instrumento ou vai se tornar um "lugar aberto"? Muda o papel do jornalista, o profissionalismo ainda é central. Sem data, Universidade de Luiss.

(5) DVOSKIN, Marcos. O jornalismo e o jornalista. Mídia e mercado, $p$. 50, outubro/2000. cionamentos anteriores, a reflexão sobre o tema não pode estar completa sem a inclusão do próprio jornalista e também de algumas considerações sobre quem são e como se comportam os receptores da informação digital.

Iniciando pelo jornalista, o verbete encontrado no Dicionário Aurélio correspondente a jornalismo diz de forma direta: "jornalismo é o exercício da profissão do jornalista". O profissional e os ambientes de atuação são âncoras de peso neste exercício sobre direitos e deveres de informar no ciberespaço tão vinculado à liberdade de expressão.

Expressiva quantidade de referências na literatura questionam o futuro do jornalista e a influência das diversas ferramentas decorrentes das tecnologias da informação - computadores potentes, softwares que funcionam como corretores e dicionários, os diálogos promovidos pela interatividade, as convergências multimídia, a irreversível introdução da narrativa hipermediática, a predominância do protocolo internet como sistema de transmissão para qualquer mídia, a digitalização e a miniaturização dos típicos equipamentos de trabalho do jornalista: o celular, a videocâmara digital, etc.

Neste ambiente o jornalista vivencia ambigüidades: sua preservação como o profissional habilitado para reportar conteúdos, a predominância dos conglomerados multimídia associados à indústria do software, as pressões do mercado leitor e suas crenças e valores pessoais.

Numa visão bem realista, Alain Accardo $^{3}$, professor conferencista da Universidade de Bordeaux-III, afirma que o discurso mediático parece convergir espontaneamente para a legitimação da ordem estabelecida e, com isso, contribuir de forma indispensável à perenidade do sistema social. Para isso, Accardo afirma que os jornalistas acabam conformando-se numa espécie de comunidade de referência para a sociedade, deixando de exercer o seu papel "conforme suas convicções" para exercê-lo "como deveriam", portanto, "como fazem todos os atores de qualquer campo social, a visão dos jornalistas se caracteriza por uma mistura em doses variáveis, conforme a posição profissional e social que ocupam, de lucidez e de ceticismo, de ver ou nãover, ou apenas de revelar".

Já Sergio Lepri ${ }^{4}$, lendário exdiretor da agência italiana ANSA, assume que o papel do jornalista está mudando numa relação direta com a evolução das ferramentas das tecnologias de informação: “...tudo isso poderia garantir, seriamente, um exercício maior da responsabilidade do jornalismo; isto é, coadjuvar no crescimento do patrimônio de conhecimentos e portanto do patrimônio cultural dos que lêem e ouvem. O pano de fundo de tudo isso sempre é, em qualquer circunstância, a consciência profissional de quem escolheu a profissão de jornalista e o senso de dignidade do próprio trabalho.[...] mas se todos os programas de que se falou - correção ortográfica e gramatical e em seguida de intervenção estilística - podem operar mesmo durante a fase de redação, de modo automático, ou seja, sem a intervenção racional ou consciente de quem escreve, não só haveria o risco de uma legitimação profissional da ignorância; haveria a certeza do fim de nossa profissão".

Lepri termina suas reflexões vinculando o futuro do jornalista ao determinismo do mercado: "Hoje ainda é difícil dizer se a internet permanecerá apenas como 'instrumento', fatalmente condicionado aos detentores deste ou daquele poder, ou então como um 'lugar' aberto à participação de todos”. E, no seu dizer, quem vai estabelecer isso infelizmente não serão os jornalistas mas, para o bem e/ou para o mal, será o mercado.

A percepção dos profissionais brasileiros é mais otimista e defensora do jornalista como o único capacitado a prover conteúdo. Apenas com a adoção de uma postura adaptativa às transformações.

Para Marcos Dvoskin ${ }^{5}$, jornalista e executivo do Grupo Rede Brasil Sul, "O jornalista não ficou assustado com as mutações tecnológicas. Ele adaptouse naturalmente, usou sensibilidade, experiência e treinamento para inovar na 
web e nas outras mídias.[...] O jornalista sabe e espalha. Claro que aquele que não se informatizou e não buscou no Inglês (a língua da globalização) a solução para um segundo idioma, limitou-se à máquina de escrever e passou a usar o rótulo de "fora de uso"'. Mas Dvoskin também deixa claro que essa reciclagem "natural" vem ocorrendo por iniciativa do próprio profissional, com pouco investimento da empresa informativa, para ocupar novos espaços e poderes no ambiente mutante do meio digital. Mas reafirma: "sua missão, porém, continua a mesma de outros tempos, anos do batuque irregular da máquina de escrever: informar. $\mathrm{O}$ bom e velho repórter continua vivo."

Por último, com relação ao internauta (ou usuário, ou leitor digital) poderíamos discorrer uma diversidade de visões com relação ao seu comportamento em ambientes provedores de informação digital. Um volume de referências que não cabem no âmbito deste ensaio.

Destacamos, apenas, algumas das suas características comportamentais típicas: o receptor da informação digital detém, sempre o poder e o domínio da escolha da informação que necessita. Com isso, o internauta navega pelos de sites jornalísticos na web em busca de objetividade, utilidade, informação rápida, clareza. Numa segunda postura comportamental, esse mesmo internauta, quando necessita aprofundar-se num determinado tema, busca sites que garantam a contextualização, a disponibilização de correlações oportunas, recursos multimídia e possibilidade de interatividade.

Jornalismo, jornalista e internautas são os atores. Será através deles que, talvez por vício (ou virtude) de formação, optamos por prosseguir nesta reflexão através de uma abordagem sistêmica e evolutiva das suas relações, mediações e questionamentos de suas atuações quanto aos direitos e deveres no espaço da comunicação digital. Nossa proposição básica, então, é discutir criticamente uma relação entre a diversidade de aspectos que devem ser considerados no campo dos direitos e deveres e a transformação de tais aspectos na medida em que a mídia (e especialmente a amplitude de seus suportes tecnológicos) assume um papel determinante na sociedade, chegando até ao cenário atual da informação e das mediações nas redes digitais.

\section{A questão nas mídias tradicionais}

Iniciando pela esfera institucional e regulatória, o direito à informação e o dever de informar são componentes fundamentais e presentes em todas as reflexões, nos diferentes códigos de ética da profissão. O Código de Ética da FENAJ - Federação Nacional de Jornalistas, é explícito quando assegura que cidadão tem direito à informação e que todo jornalista deve ter acesso à informação para cumprir o seu papel intrínseco de mediação social - o dever de informar.

Com a mesma conotação, o tema é tratado pela Constituição Federal, pela Lei de Imprensa, pelos organismos internacionais e por uma infinidade de associações representativas dos profissionais da comunicação. Evidenciam-se a privacidade, a liberdade de manifestação do pensamento, o direito à informação através de quaisquer meios de comunicação social.

O que emerge da esfera institucional são as relações conflitantes entre a ética do indivíduo, a ética da profissão e a ética da empresa informativa onde este profissional está vinculado.

Com isso, evoluímos para um segundo patamar de reflexão: a presença da mídia como interveniente e não apenas mediadora, em diferentes esferas da sociedade. Falamos, então, de empresas informativas configuradas em grandes complexos multimídia, suas posturas de isenção e objetividade perante os fatos sociais, seus papéis de formação da opinião para o público e seus interesses empresariais e sociais. Falamos também dos contextos social, político e econômico nos quais a empresa de mídia se insere e das relações que ela estabelece nesses contextos.

Diante disso, "direito à informação e dever de informar" passa, ou melhor, assume a lógica do acesso à 
(6) FUUER, Jack. News Values in the Information Age. Chicago; University of Chicago Press, 1997 (7) Manual de Redação da Folha de S. Paulo. São Paulo: Folha deS. Paulo, 1995. Acessado pela internet em http://www.uol.com.br/ folha;arquivos.htm, em 31/10/ 2202.

(8) ROSSI, Clóvis. O que é Jornalismo? São Paulo: Brasiliense, 2000 (Coleção Primeiros Passos).

(9) VAIA, Sandro. Vícios e virtudes do jornalismo brasileiro. Instituto Gutenberg, acessado via internet. (10) BUCCI, Eugênio. Sobre ética e imprensa. São Paulo: Cia. das Letras, 2000. (11) KUCINSKI, Bernardo. A síndrome da antena parabólica. São Paulo: Editora Fundação Perseu Abramo, 1998. informação proporcionada pela abrangência e posicionamento editorialempresarial dos conglomerados multimídia. Portanto, abre-se uma nova seqüência de questões: acesso a quais informações? Controladas ou filtradas por quem? Sob quais critérios? Sob qual definição do que seja interesse público ou invasão da esfera privada?

Impossível tratar do acesso à informação sem a inserção do leitor, espectador, ouvinte ou usuário em suas relações com as empresas informativas: quem será informado, através de qual meio, sobre qual conteúdo e, novamente, sob quais critérios e filtros?

Pela lógica do publisher e do empresário de comunicação não se oferecem muitas dúvidas. Jack Fuller ${ }^{6}$, Presidente do Conselho Editorial da Tribune Co., um dos maiores conglomerados multimídia dos Estados Unidos, afirma que a empresa assume o compromisso de relatar e opinar sobre as temáticas globais que a mesma considera serem como de interesse e de significado para o público a quem serve.

O Manual de Redação da Folha de S. Paulo ${ }^{7}$, considerado referência para a compreensão do exercício ético do jornalismo, afirma literalmente que notícia e informação são considerados como a mercadoria básica para o grupo Folha. Inclui ainda, que o processo de produção desta mercadoria deverá estar rigidamente pautado por princípios como isenção, objetividade, nenhuma vinculação da notícia aos interesses comerciais da empresa, a versão de todas as vozes, entre outros preceitos.

Pela lógica dos profissionais percebem-se as mesclas entre valores dos indivíduos e obrigações profissionais. Jornalistas respeitados, como Clóvis Rossi, editorialista da mesma Folha de S. Paulo, e Sandro Vaia, atual diretor de redação de $\mathrm{O}$ Estado de S. Paulo, seguem pela linha de que o acesso à informação é a base para o exercício do papel de mediação do jornalismo. Mas, ambos não esquecem de incluir o mercado em suas considerações.

Assim, Rossi no primeiro parágrafo de seu livro "O que é o jornalismo"8 afirma que "o jornalismo é a fascinante batalha pela conquista das mentes e corações de seus alvos: leitores, telespectadores e ouvintes". $V a^{9} a^{9}$, por sua vez, afirma que a função do jornalista é fazer a mediação entre a informação bruta e a informação útil. Utilidade esta vinculada ao valor da informação como produto.

Eugênio Bucci ${ }^{10}$ sintetiza através da ética: "conseqüência dos monopólios dos meios de comunicação, da pressa inerente ao jornalismo, da briga acirrada e diária pela notícia exclusiva ou da guerra pela audiência, o fato é que os jornalistas e seus patrões muitas vezes se afastam da conduta ética e oferecem ao público uma informação de má qualidade. [....] Neste momento em que a lógica do espetáculo e do entretenimento contamina os veículos jornalísticos, em que as megafusões de empresas de comunicação aumentam como nunca o poder da mídia em todo o mundo, refletir sobre ética e imprensa é de primeira necessidade".

Podemos, neste ponto, considerar que o direito e o dever de informar, desde que pautado pelo acesso à informação e liberdade de expressão, é na realidade um processo de agregação de valor constituído pela caracterização dos fatos, contextualização, hierarquização e clareza. Lembrando que agregação de valor é fator determinante para a competição empresarial e, no caso da empresa informativa, um processo que se desencadeia a partir de uma necessidade informativa "criada" para o leitor. Chegamos, agora, ao terceiro patamar da reflexão: a relação da mídia com o status do poder político, social e econômico vigente. Uma relação que pode variar num espectro que vai da oposição ferrenha até vergonhosos níveis de promiscuidade. Não nos esquecendo de qual mídia falamos: aquela que agrega valor à mercadoria notícia.

Embasando a reflexão, recorremos a Bernardo Kucinski11, que trata da questão em seu livro "A Síndrome da Antena Parabólica". Partindo de um cenário de predomínio das mídias tradicionais - imprensa, rádio e TV Kucinski discute o papel dos meios de comunicação na produção do consenso 
coletivo e na definição da agenda de discussão da sociedade. Na abordagem apresentada, o direito e dever da informação centra-se na definição do que seja espaço público em sociedades polarizadas.

A professora Margarethe Born Steinberger ${ }^{12}$, da PUC de São Paulo, tam bém segue na mesma trilha, avaliando que o jornalismo moderno é uma instituição organizada segundo o modelo liberal, sustentado, ao mesmo tempo, por um compromisso com a esfera pública e um desejo de autonomia e independência. Assim, evidenciam-se conflitos de interesse como relação com as classes dominantes e submissão de mídia à ideologia do poder político vigente. $\mathrm{Na}$ verdade, são aspectos que nos deixam ainda mais distantes do conceito fundamental de que todo cidadão tem direito à informação e que toda instituição de mediação tem o deve de informar a todos os cidadãos.

Se analisarmos a evolução da mídia como um poder social, na medida em que o processo de industrialização do produto informativo foi se sofisticando tecnologicamente e, portanto, seu conteúdo se massificando, a questão dạ liberdade de informar e do acesso à informação foi também se transformando.

Nem jornalistas e muito menos os receptores podem controlar diretamente o conteúdo dos produtos informativos. O que mais vemos hoje são empresas informativas que produzem a partir do determinismo de hierarquias corporativas que sustentam seu capital ou suas posições sociais bancos, investidores capitalistas, partidos políticos e o próprio Estado.

$\mathrm{Na}$ verdade, apesar da sofisticação dos meios tecnológicos, tal cenário apresenta uma grande massa de receptores passivos, onde poucos podem se utilizar dos meios de comunicação para expressar seus pontos de vista. No lugar de atores, a audiência assume um papel de espectador de pronunciamentos e posicionamentos de profissionais e gurus mediáticos.

Questionaremos tal cenário sob . a realidade da World Wide Web em item adiante neste ensaio.

Resumindo, falamos da tradicional proposição de Maxwell McCombs ${ }^{13}$ - o agenda setting - , onde a mídia mais do que cumpre seu papel básico de nos informar sobre o que - pensar e avança em posicionar-se junto aos leitores sobre como pensar temas definidos como de interesse público por uma mídia controlada geralmente por interesses nem tão coletivos ou públicos assim.

Kucinski descreve que, no caso do Brasil, assuntos estratégicos -ou seja, a definição do interesse público-, são pautados pela elite dominante. Com mais um agravante: uma elite que funciona em nossa sociedade simultaneamente - como fonte, protagonista e sustentadora dos fatos (além de se constituir como o público principal que tem acesso aos meios de comunicação no país).

Passando para a esfera internacional, foi marcante a discussão sobre a cobertura da imprensa norte-americana (e conseqüentemente dos demais países) sobre o evento Word Trade Center - WTC. O conflito entre autonomia e independência tão valorizado na sociedade americana foi claramente confrontado com o poder do governo em determinar a não divulgação de conteúdos que poderiam "estimular" novos ataques terroristas.

No caso, esvaiu-se pelo ralo, em questão de horas, o direito e o acesso à preconizada realidade dos fatos. $\mathrm{O}$ próprio exercício de mediação do jornalismo foi truncado em nome da segurança e do equilíbrio de forças reguladoras da paz mundial.

À época, a declaração conjunta das redes $\mathrm{NBC}, \mathrm{CBS}, \mathrm{ABC}$ e $\mathrm{CNN}$ comprometeram o direito e o dever de informar. Mas, ao mesmo tempo, abriram espaço para o cidadão buscar fontes não compactuadas - ou compactuadas à forças oponentes - para buscar uma tentativa de formação de opinião. A TV Al-Jazeera entra nessa esfera de opções.

Além da reflexão entre definição de interesses, esse terceiro patamar deverá incluir em aprofundamentos e
(12) STEINBERGER, Margarethe Born. Desmidiatizar o pensamento: economia das representações e subdesenvolvimento informacional no Brasil. In São Paulo em Perspectiva - Comunicação e Informação, vol.12, n4. São Paulo: Fundação SEADE. (13) MCCOMBS, Maxwell, e SHAW, Donald. The evolution of agendasetting research: twenty five years in the marketplace of ideas. Doaumento xerografado. 
discussões futuras a questão da credibilidade da mídia, da construção da marca jornalística em torno da sua credibilidade - os valores fundamenta - diante do dever de informar.

Sob o ponto de vista do receptor resta a questão da vulnerabilidade do que sejam valores e credibilidade de uma marca jornalística. Uma vulnerabilidade que nos faz considerar no mínimo razoável a pantomima mediática armada por Robert de Niro e Dustin Hoffman no filme."Mera Coincidência", aplicada ao evento WTC, nos faz conjecturar sobre o acordo de "exclusivas" celebrado entre Al-Jazeera e CNN. no conflito do Afeganistão, poderia estar embasado nessa submissão de interesses.

São situações que ficam muito explícitas nas mídias que privilegiam a oral idade e a imagem. E. num grau men nas mídias que exigem capacidade de leitura - as impressas.

\section{Direitos e deveres da informação no ciberespaço}

Chegamos, por fim, ao quarto e último patamar de nossa reflexão: como se define direito à informação e o dever de informar nas mídias digitais que transitam na imaterialidade do ciberespaço? Mantêm-se as mesmas questões levantadas para as mídias tradicionais? (considerando que a internet também é uma mídia)

Partimos de posições já bastante discutidas por outros autores quanto à limitação ao acesso à informação digital por aspectos sócio-econômicos; e também das discussões sobre a imposição de "filtros" à informação; além de considerar como dados as questões relativas à inclusão ou exclusão digital. Também assumimos a definição de que a web aqui discutida é aquela que dissemina informações e notícias e que, portanto, se encaixa nos aspectos de acesso e direito à informação.

As mídias baseadas em redes digitais de informação e comunicação possuem a característica intrínseca de liberdade de expressão e opinião, por conta de sua própria configuração técnica. E, simultaneamente, a característica paradoxal de uma aces- sibilidade vinculada a equipamentos que ainda não atingiram a massificação similar (e, portanto, ao barateamento) à dos aparelhos de rádio e TV.

E também possuem o vínculo de acessibilidade com a conexão. Mídia digital não existe sem o seu suporte conectado a uma linha telefônica ou à bandas de tráfego acelerado de sinais elétricos. Por aqui. a questão envereda pela proposição, aprovação e regulamentação de políticas de telecomunicação dos diferentes países, situação sócio-econômica e as conseqüentes inserções do tema à lógica neoliberal dos sistemas econômicos globalizados.

Para fins desta reflexão, as características intrínsecas e paradoxais das mídias digitais estão sendo consideradas como dados e, a partir deles, ordesenvolvemos o restante do ensaio.

Ao falarmos de mídias digitais, também estaremos considerando a World Wide Web como o canal de difusão principal. Falamos, assim, um "direito à informação e um dever de informar" para um contingente de cidadãos incluídos digitalmente, ou seja, equipados pelos suportes tecnológicos. Mas também gostaríamos de incluir a mesma leitura desta reflexão sob o ponto de vista oposto e mais real da sociedade contemporânea: o contingente dos excluídos digitalmente, que reforçam a posição do papel da elite na definição da esfera pública e privada.

O cenário descrito é avaliado pelos pensadores do ciberespaço conforme a sua relação de proximidade e defesa do papel das mídias digitais na sociedade contemporânea.

Se admitirmos que vivenciamos a sociedade da informação estaremos navegando por diferentes graus de idealismo que passam por Pierre Lévy, Manuel Castells, Anthony Giddens, Nicholas Negroponte e outros; mas também deveremos incluir antagonistas como Paul Virillio e seus seguidores.

No mundo da informação digital, as já consideradas até aqui perspectivas de "público", "mercado", "agendasetting" e até mesmo "democracia" mudam e, algumas vezes, caem por terra.

Para o sociólogo catalão Manuel 
Castells, a liberdade de expressão que a web possibilita deve ser considerada como a pedra angular da democracia digital. Mas também alerta que é um exercício democrático parcial, pois o ciberespaço é povoado do que chama internautas ativos - capazes de selecionar seus próprios circuitos comunicacionais multidirecionais - e o enorme contingente de internautas passivos - que recebem pela web um conjunto de informações préempacotadas e satisfazem-se com isso, por suas próprias limitações.

Considerando a posição de Castells "direito e dever" na web possuem perspectivas diferentes conforme o perfil do receptor. Castells, em recentes textos divulgados ao longo de 2001, preparatórios à publicação de um novo livro, evidencia algumas características que relacionam "direito e dever" à informação, aos digitalmente incluídos:

- a emergência da "cultura do hacker" conferindo à Internet a única forma de comunicação humana horizontal e sem controle desta horizontalidade;

- a vantagem do recurso do hipertexto que possibilita a inserção de qualquer tipo de opinião no sistema comunicacional da grande rede, ignorando os filtros; - a inclusão de mais uma característica paradoxal: a internet como principal instrumento de antiglobalização, pois possibilita a formação de aglutinações de grupos de interesse que convergem através da web, quando querem provocar um impacto mediático coletivo.

Tais idéias recentes de Castells são reforçadas por outros pesquisadores espanhóis como Rosa Franquet, Emili Prado e Xosé Lopez e Oscar Jaramillo Castro ${ }^{14}$.

Este último resume e amplia as colocações de Castells e chama atenção para o aspecto de controle que sempre emerge quando se fala em informação na web: “...o ponto que devemos ter claro é que na chamada era digital nos adentramos em um mundo de zeros e uns, sim ou não, aceso ou apagado, obrigando-nos a ser precavidos ante qualquer afirmação com relação a tentativas de controle da grande rede".
O autor toma por base informações divulgadas na própria mídia de que serviços de inteligência de diversos países já podem controlar todas atividades dos cidadãos realizadas via web, incluindo o e-mail; e também a proposta do governo Bill Clinton de controle da web através da publicação do polêmico Telecommunications Decency Act.

A web, considerada em sua essência mais pura e como principal alavanca de uma democracia coletiva defendida por Pierre Lévy, poderia ser o melhor espaço mediático para o exercício do direito à informação e o dever de informar.

Se tal liberdade fosse real, no caso já citado do WTC, teríamos disponíveis para qualquer usuário na grande rede as informações filtradas pelo Pentágono e reproduzidas nos sites da CNN ou do Washington Post; os questionamentos aos filtros e edições em tom de censura do NY Times; uma diversidade de sites instrutivos, evangelizadores e convocatórios da Jihad Islâmica; com a ajuda de algum mecanismo de busca mais preciso, poderíamos até encontrar mensagens de Bin Laden convocando fiéis; e-mails personalizados enviados e assinados por George W. Bush dirigido a cada cidadão norte-americano conectado e, portanto, com potencial de gastar seus dólares para re-insuflar a economia americana.

Nessa situação extrema e hipotética tudo pode, tudo é acessível e a construção do "fio condutor" informativo recai nas mãos do internauta. A questão é: que tipo de informação vai parar nas telas dos internautas, já que a tecnologia possibilita tudo?

Castro ${ }^{15}$ categoriza os problemas do direito à informação na web da seguinte forma:

I) Tentativas de censura e controle por parte dos Estados;

II) Existência de controles indiretos: -sistemas de autenticação e filtragem; -encriptação e a perda de privacidade; -limitações ao acesso e o monopólio dos softwares;

-predomínio dos grandes grupos econômicos na web.

Como resposta e essas diferen-
(14) CASTRO, Oscar Jaramillo. Derecho a la Información en la Web: una resivión conceptual. Universidade Complitense de Madrid, documento de programa de doutoramento, 2001. (15)Id. Ibidem. 
tes modalidades de cerceamento ao ciberespaço, o autor aponta soluções e formas de driblar controles utilizados pelos sites que objetivam expressar sua opinião. Geralmente são saídas oferecidas pela própria tecnologia, como sites "espelho" em países menos controladores. Também destaca que, permeando cerceamentos e soluções, a web transforma as características de difusão, delegadas pelas sociedades aos meios de comunicação (empresas informativas) e de investigação, de responsabilidade dos jornalistas. No ciberespaço tais relações ficam circulares, misturando os dois conceitos.

Um outro aspecto levantado tanto por Castells quanto por Castro refere-se à atemporalidade de informações na web, uma vez que passado, presente e futuro "tornam-se" sempre "presente" quando acessados e visualizados através da tela do microcomputador. Com isso, o momento da difusão de uma informação não ocorre quando o emissor faz o upload da mesma na rede, mas quando algum internauta navega pela página e a visualiza na tela.

Com isso, segundo Castro, "Também temos que observar que se definimos o direito à informação como os direitos de receber, investigar e transmitir mensagens veremos que este se aplica perfeitamente ao que ocorre na web e, portanto, deveríamos no centrar nos problemas do estabelecimento de responsabilidades e em definir qual o momento da emissão em função da existência desse tempo atemporal. [...] por mais contraditório que pareça o maior problema (do direito à informação na web) está em garantir a liberdade, já que os mecanismos de burlar censura são os mesmos para burlar a liberdade..."

Mas, como ficam os digitalmente excluídos?

Neste cenário apontado por

(16) LAJE, Nilson. A bolha ideológica e o destino do jornalismo. Sala de Prensa, n॰37, nov.2001, ano 3 vol.2. acessado em www.saldeprensa.org/art286.htm pectos de direitos e deveres de informar através das redes digitais de informação.

\section{Anotações finais}

Discutir "direito e dever" de informar depende do foco a ser analisado. E também, depende da crença em sua existência mais pura e descontaminada.

Sabemos que a realidade do mundo digital não é tão hipotética assim, muito de suas características são transportadas do mundo real e por conta de sua própria configuração arquitetônica o exercício pleno do acesso à informação e da inclusão digital é uma utopia.

Conhecida como o espaço comunicacional mais livre e sem controle, a web é e vem sendo o espaço comunicacional que permite mais a inserção de mecanismos de controle sutis, imperceptíveis e extremamente invasivos, mantendo a aura da liberdade e do caos digital.

Não fossem tais possibilidades de controles cookies, plug-in's invisíveis, certificados de identificação, monitoramento de comportamento de uso das páginas - não poderíamos falar e discutir sobre a informação digital como uma nova possibilidade de competição entre conglomerados de mídia mundial. Diante disso, o direito à informação e o dever de informar na mídia digital apenas potencializa todas as demais reflexões ancoradas nas mídias tradicionais.

Com isso, e apesar dos céticos e críticos que preconizam o fim do jornalismo e a emergência de emissores individuais, podemos afirmar que repousa no jornalista e nos demais profissionais da comunicação a responsabilidade pela garantia de liberdade de informação na web.

Segundo Nilson Laje" "Sem informação jornalística - e pouco importa se ela agrada ou desagrada, se lhe motiva paixão ou repulsa - o homem contemporâneo não consegue orientarse na vida civil, profissional e mesmo afetiva; os mercados regridem em dinamismo e agilidade; numa era de especialidades, especialistas e tribos, pelo jornalismo que se consegue ter 
contato com o que pensam os outros". Para o autor, mesmo com todos os recursos tecnológicos digitais, como os agentes inteligentes, softwares de gestão de conteúdo, entre outros, indica que a posse de canais de comunicação deixará de ser relevante como instrumento de controle social.

Na realidade, a "imaterialidade" do ciberespaço acaba por ampliar o espaço a quaisquer vozes que queiram exercer o direito de liberdade de expressão; por transferir o caráter de mediação - do dever de informar também a quaisquer vozes e transferir para camadas cada vez mais elitizadas, segmentadas e reduzidas do planeta definições dos assuntos de interesse público; além de interferir naquilo que seria esfera privada do cidadão que está à frente de interfaces cada vez mais "inteligentes", que "sem querer" lhes tiram o direito à privacidade e à escolha de sua vivência sem coletividade.

Poderíamos inferir diante de todas as reflexões que o direito à informação e o dever de informar no meio digital ultrapassa os limites do jornalismo em si e instala-se na esfera da cidadania e da civilidade. Mas, ainda segundo Lage "a prática tem mostrado que, entre informações de origem duvidosa, os produtos de vaidade, os delírios paranóicos, as mais estranhas pregações e mentiras, o internauta procura informação profissional e competente, seja ela didática, jornalística, estética, erótica ou qualquer outra. Isso não é novo: embora câmaras fotográficas de alta qualidade existam, há décadas, ao alcance das pessoas de salário médio, os fotógrafos profissionais não desapareceram porque é outra a sua relação com o equipamento e, de modo geral, com o tema retratado".

Retomamos, por fim às questões iniciais: qual o papel do jornalismo nesse panorama? Qual a configuração do profissional num cenário onde as funções de difusão e investigação podem também ser exercidas pelos antigos leitores (anteriormente passivos que no ciberespaço passam a interagentes)? Cabe na web o exercício do direito à informação e o dever de informar aos sites informativos?

Acreditamos que todas essas respostas concentram-se numa função, num papel e numa práxis jornalística ainda a serem configuradas e absorvidas: as artes da mediação e de narrativas não lineares. A partir disso, direitos e deveres retomam suas funções naturais na sociedade, inclusive no ciberespaço.

\section{Bibliografia do Artigo}

ACCARDO, Alain. Derrière la subjectivité des journalistes. Le

Monde Diplomatique, Paris, França, 2000.

BUCCI, Eugênio. Sobre ética e imprensa. São Paulo: Companhia das

Letras, 2000.

CASTRO, Oscar Jaramillo. Derecho a la Información en la Web:

una resivión conceptual. Universidade Complitense de Madrid, documento de programa de doutoramento, 2001.

CHAPARRO, Manuel Carlos. A pragmática do jornalismo. São Paulo: Summus, 1993.

CORRÊA, Elizabeth Saad. As estratégias da desconstrução: sobre o uso de estratégias diferenciadas por empresas informativas

na internet São Paulo: ECA-USP, Tese de Livre-Docência, 2001. 
DVOSKIN, Marcos. O jornalismo e o jornalista. Mídia e mercado, 2000.

FULLER, Jack. News Values in the Information Age. Chicago: University of Chicago Press, 1997.

KUCINSKI, Bernardo. A síndrome da antena parabólica. São Paulo: Editora Fundação Perseu Abramo, 1998.

LAJE, Nilson. A bolha ideológica e o destino do jornalismo. Sala de Prensa, ${ }^{\circ} 37,2001$, ano 3, vol.2. www.saladeprensa.org

LEPRI, Sergio. Novos programas, novas máquinas: a internet vai permanecer como um instrumento ou vai se tornar um "lugar aberto"? Muda o papel do jornalista, o profissionalismo ainda é central. Universidade de LUISS, Itália.

Manual de Redação da Folha de S. Paulo. São Paulo: Folha de S. Paulo, 1995.

MCCOMBS, Maxwell, e SHAW, Donald. The evolution of agendasetting research: twenty five years in the marketplace of ideas. Public Opinion Quarterly, 74(4), p703-717

ROSSI, Clóvis. O que é Jornalismo? São Paulo: Brasiliense, 2000.

STEINBERGER, Margarethe Born. Desmidiatizar o pensamento: economia das representações e subdesenvolvimento informacional no Brasil. In São Paulo em Perspectiva - Comunicação e Informação, vol.12, nº 4. São Paulo: Fundação SEADE.

VAIA, Sandro. Vícios e virtudes do jornalismo brasileiro. Instituto Gutenberg. 